\title{
Curcuma siamensis (Zingiberaceae, Zingibereae), a new species of Curcuma subgen. Ecomatae from Southeastern Thailand
}

\author{
PIYAPORN SAENSOUK ${ }^{1}$, THAWATPHONG BOONMA ${ }^{2}$, SURAPON SAENSOUK ${ }^{3, \bullet}$ \\ ${ }^{1}$ Plant and Invertebrate Taxonomy and Its Applications Unit Group, Department of Biology, Faculty of Science, Mahasarakham University. \\ Kantarawichai District, Maha Sarakham, 44150, Thailand \\ ${ }^{2}$ Brio Botanical Research Garden. 53 M.5 Ban Mai Village, Phikun Ok, Ban Na District, Nakhon Nayok 26110, Thailand \\ ${ }^{3}$ Plant and Invertebrate Taxonomy and Its Applications Unit Group, Walai Rukhavej Botanical Research Institute, Mahasarakham University. \\ Kantarawichai District, Maha Sarakham, 44150, Thailand.`email: surapon.s@msu.ac.th
}

Manuscript received: 7 October 2021. Revision accepted: 7 November 2021.

\begin{abstract}
Saensouk P, Boonma T, Saensouk S. 2021. Curcuma siamensis (Zingiberaceae, Zingibereae), a new species of Curcuma subgen. Ecomatae from Southeastern Thailand. Biodiversitas 22: 5239-5246. Curcuma siamensis Saensouk \& Boonma sp. nov. (Zingiberaceae: Zingibereae) belonging to the genus Curcuma subgenus Ecomatae, as herein described and illustrated discovered in Chachoengsao Province, Southeastern Thailand during our exploration of Zingiberaceae family in Thailand and in preparation for the revision of the genus Curcuma for the Flora of Thailand project. It is similar to Curcuma rangsimae Boonma \& Saensouk in having terminal inflorescences between the leaf-sheaths, emerging at the basal of the pseudo-stem, lacking coma bract, yellow flowers, presence of epigynous glands, and anther spurs make this plant most similar to, which are also distributed in this nearby area too. But differ in having leaves narrowly elliptic, narrower and shorter in size 18-36 $\times 6-8.5 \mathrm{~cm}$, upper midrib reddish; thyrse shorter and smaller (5-6.5 cm long, 4-5 cm in diam.); peduncle glabrous; bracts per inflorescence 10-15 in number, fused almost only at base; corolla lobes white, longer and narrower 17-18.3 × 6-7.8 mm; staminodes uniquely obovate-rhombic; labellum ovate-trullate; filament 4.4-4.5 mm long; anther longer c. $8 \mathrm{~mm}$ long, spurs pointing outward in front view, with anther crest apex retuse (vs. C. rangsimae having leaves narrowly elliptic to oblanceolate, 40-70 × 12-20 cm, upper midrib green; thyrse 12-20 cm long, 7.8-9.5 cm in diam.; peduncle pilose; $25-48$ in number, connate $1 / 4$ to $1 / 3$ at base; corolla lobes light pale yellow, $15-17 \times 9-12$ mm; staminodes asymmetrical trullate-ovate; labellum ovate; filament 6-7 mm long; anther 6.3-6.9 mm long, spurs pointing downward in from view, with anther crest apex rounded). Based on the results of the morphological comparison and examination of all allied species in the same genus were found to be inconsistent with any species, especially in the subgenus Ecomatae. A comprehensive description, illustration, photographs, ecology, etymology, distribution and a revised key to 21 species of Curcuma subgenus Ecomatae in Thailand are provided.
\end{abstract}

Keywords: Curcuma rangsimae, C. cotuana, Chachoengsao, Flora of Thailand, taxonomy, Zingiberales

\section{INTRODUCTION}

Curcuma $\mathrm{L}$. is one of the beautiful flowering plants belonging to the family Zingiberaceae with Curcuma longa L. as the type species and is widely distributed from India to Southeast Asia and southern China, to Papua New Guinea, and Northern Australia (Larsen and Larsen 2006; Leong-Škorničková and Newman 2015; Sirirugsa et al. 2007). The first taxonomic study of this genus in Thailand was conducted by Professor Puangpen Sirirugsa, who reported thirty species of Curcuma, but seven species of which were not yet identified up to species level (Sirirugsa 1966). In 2007, Sirirugsa et al. suggested classifying species of Curcuma in Thailand into five groups based on the presence or absence of epigynous glands, the shape of the anther and some characters including coma bracts shape. Later studies of Záveská et al. (2012) and LeongŠkorničková et al. (2015) proposed and supported the classification of Curcuma into three subgenera namely Hitcheniopsis (Baker) K. Schum., Curcuma L, and Ecomatae Škorničk. \& Šída f. and also included some genera and species to be classified under the Curcuma. Since then, many new species of Curcuma with all three subgenera have been continuously discovered in Thailand up until now. A recent publication by Maknoi et al. (2021) reported two new species of Curcuma subgenus Ecomatae from Thailand. These two new species make the total number of subgenus Ecomatae to 20 species for Thailand, and a total number 32 species across its geographical range.

In this study, we found an undescribed species of Curcuma belonging to subgenus Ecomatae in Chachoengsao Province, Southeastern Thailand, during our exploration for the diversity of family Zingiberaceae in Thailand in preparation for the revision of the genus for the Flora of Thailand project. This plant is similar to Curcuma rangsimae Boonma \& Saensouk which can be found in the nearby area. After a careful morphological examination and comparison of all allied species within subgenus Ecomatae, results revealed that the species does not match any other known Curcuma species and is divergent. We, therefore, describe it here as Curcuma siamensis, a species new to science. A comprehensive description, illustration, color photographs, ecology, etymology, and distribution are provided below as well as a revised key to the 21 species of Curcuma subgenus Ecomatae in Thailand to facilitate easy identification. 

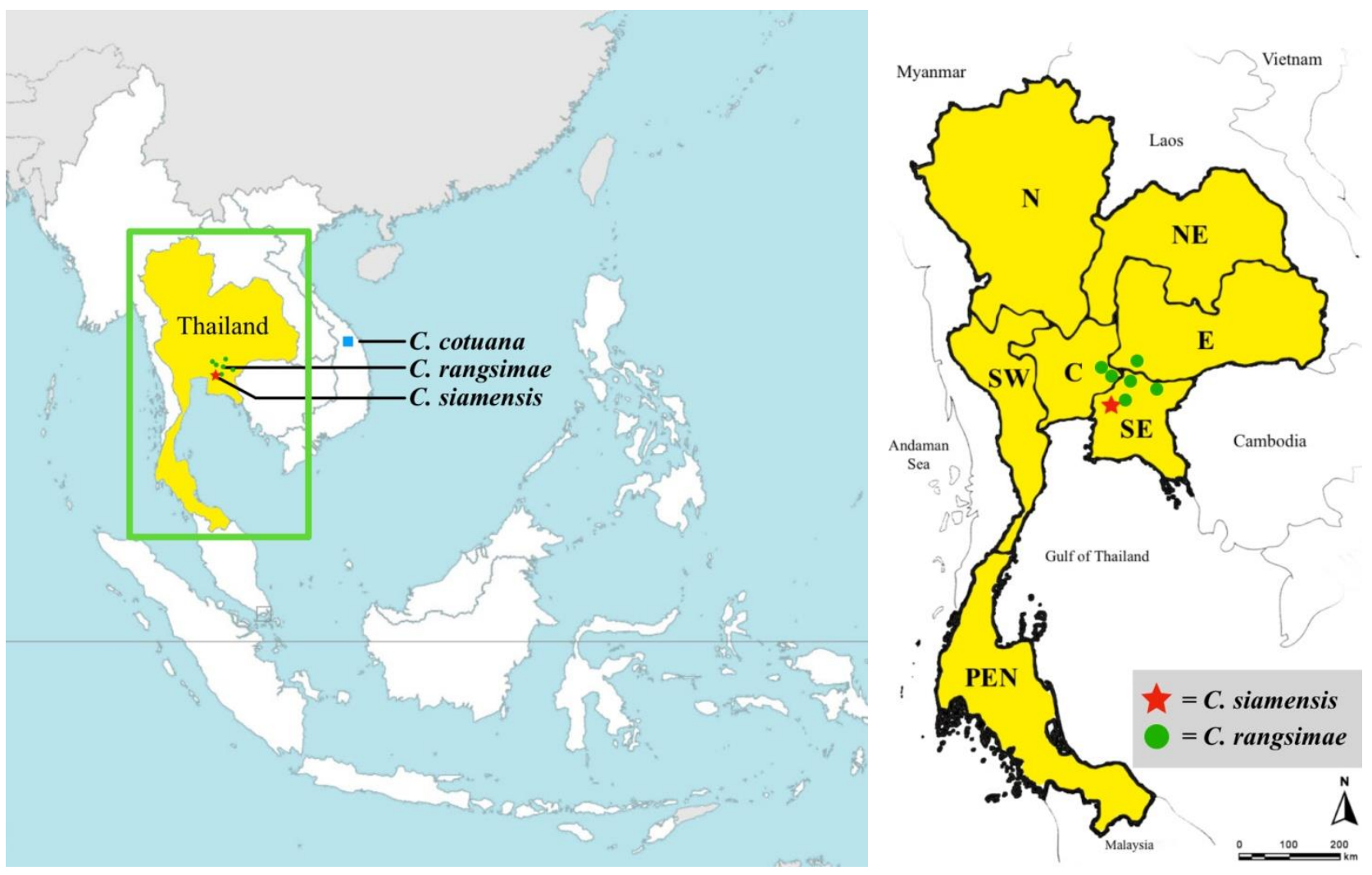

Figure 1. Distribution map of Curcuma siamensis Saensouk \& Boonma sp. nov. and its allies. Abbreviations in the map are the floristic region after the "Flora of Thailand" project which N: Northern; NE: Northeastern; SW:Southwestern; C: Central; E: East; SE: Southeastern; and PEN: Peninsular. (Southeast Asia map from https://aseanup.com/wp-content/uploads/2015/04/ASEAN-map-whiteblank.jpg)

\section{MATERIALS AND METHODS}

Plant materials were collected from Chachoengsao Province, Southeastern Thailand (Figure 1) from August 2018 to 2020. Measurements were recorded from living and spirit collection, and were deposited at KKU and additional specimens were deposited at Brio Botanical Research Garden. Type specimens of species that are similar in morphological were compared and verified. The morphological descriptions in all species of accepted species, especially species distribution in Thailand and neighboring countries, available digital images and information online e.g. photographs of Herbarium specimen with details from Kew's Herbarium or powo.science.kew.org (Kew Science 2021), Queen Sirikit Botanic Garden Herbarium (QBG), including existing published literature of Curcuma were also compared in this study.

\section{RESULTS AND DISCUSSION}

Curcuma siamensis Saensouk \& Boonma (Zingiberaceae: Zingibereae) was described here as a new species of Curcuma which has been found distributed only in the forest in Chachoengsao Province, Southeastern Thailand (Figures 3-4). It was named from "Siam" the former name of Thailand refers to the geographical origin of this new species which was first reported from Thailand. Detailed descriptions along with illustrations, photographs, distribution (Figure 1), ecology, and uses have been provided, the morphological comparison with its allies species in Table 1, followed by a revised key to species of Curcuma subgen. Ecomatae in Thailand.

\section{Taxonomic treatment}

Curcuma siamensis Saensouk \& Boonma, sp. nov. Figures 3-4, Table 1-Subgen. Ecomatae

The new species is similar to $C$. rangsimae Boonma \& Saensouk. but differ in having leaves narrowly elliptic, narrower and shorter in size $18-36 \times 6-8.5 \mathrm{~cm}$, upper midrib reddish; thyrse shorter and smaller $(5-6.5 \mathrm{~cm}$ long, 4-5 cm in diam.); peduncle glabrous; bracts per inflorescence $10-15$ in number, fused almost only at base; corolla lobes white, longer and narrower 17-18.3 × 6-7.8 $\mathrm{mm}$; staminodes uniquely obovate-rhombic; labellum ovate-trullate; filament 4.4-4.5 mm long; anther longer c. 8 $\mathrm{mm}$ long, spurs pointing outward in front view, with anther crest apex retuse (vs. C. rangsimae having leaves narrowly elliptic to oblanceolate, $40-70 \times 12-20 \mathrm{~cm}$, upper midrib green; thyrse $12-20 \mathrm{~cm}$ long, $7.8-9.5 \mathrm{~cm}$ in diam.; peduncle pilose; $25-48$ in number, connate $1 / 4$ to $1 / 3$ at base; corolla lobes light pale yellow, 15-17 × 9-12 mm; staminodes asymmetrical trullate-ovate; labellum ovate; 
filament 6-7 mm long; anther 6.3-6.9 mm long, spurs pointing downward in from view, with anther crest apex rounded).

Type: Thailand, Chachoengsao Province, Phanom Sarakham District, 172 m, Boonma 39, 10.08.2018 (holo $\mathrm{KKU}$ !; iso $\mathrm{BK}$ !)

Perennial herb, Primary rhizome ovoid with small and long branched downward, brownish externally, pale yellow internally, $2-3 \times 1.8-2.5 \mathrm{~cm}$, Root fibrous with tuberous roots. Leafy shoot $45-60 \mathrm{~cm}$ tall. Sheathing bracts $1-2,5-$ $14 \mathrm{~cm}$ long, green with a brownish-red tinge or brownishred, apex mucronate. Leaf-sheaths 4-8(-9), green or green with brownish-red tinge, distichous, $8-15 \mathrm{~cm}$ long, glabrous; ligule bilobed, 3-4 mm long, apex rounded; petiole green, canaliculate, $8-10 \mathrm{~cm}$, glabrous. Lamina narrowly elliptic, slightly recurved, $18-36 \times 6-8.5 \mathrm{~cm}$ (the first leaf usually shortest and narrowest), apex acuminate, base attenuate, margin slightly undulate, hyaline, translucent white, adaxially green with reddish patch along the midrib, abaxially paler green, glabrous on both surfaces. Inflorescence terminal between the leaf sheaths, emerge at the base of the pseudostems; thyrse $5-6.5 \mathrm{~cm}$ long, 4-5 cm in diam. in the broadest part; peduncle pale green to white, c. $6 \mathrm{~mm}$ in diameter, glabrous. Coma bract absent. Fertile bracts $10-15$ in number, $3.5-5.4 \times 1-2.8 \mathrm{~cm}$, apex mucronate, whitish to pale green or with a various reddish tinge, fused only at base, puberulent especially at the distal part (may not be visible to the naked eye), lowest bracts are the longest and broadest, upper bract shorter and smaller. Flower various shades of pale yellow, open form, 5.3-5.5 cm. Bracteoles subulate, 8-14 × 1.6-2 mm, translucent white, ciliate. Calyx tubular $18.3-18.5 \mathrm{~mm}$ long, apex 3-lobed (two lobes apex mucronate, mucro c. $1.5 \mathrm{~mm}$ long, another one lobe apex obtuse), with unilaterally incision up to $8 \mathrm{~mm}$ long, white, glabrous except the margin of the three lobes have a few hairs. Floral tube tubular and enlarged to conical at distal part, $3.28-3.3 \mathrm{~cm}$ long, pale yellow to white at base, glabrous except at distal part puberulent; dorsal corolla lobe 1, narrowly triangular, $17.6-18.3 \times 7.6-7.8 \mathrm{~mm}$, apex mucronate (mucro c. $3 \mathrm{~mm}$ long), slightly cucullate, white, glabrous; lateral corolla lobes 2 , narrowly triangular, 17.0 $17.5 \times 6.3-6.5 \mathrm{~mm}$, apex acute slightly mucronate, slightly cucullate, white, glabrous. Lateral staminodes 2, uniquely obovate-rhombic, $16.2-16.8 \times 9.5-10 \mathrm{~mm}$, apex obtuse, yellow at base gradually fade to whitish-yellow at the margin and distal part (or various shades of pale yellow), puberulent. Labellum ovate-trullate, 17.8-18.2 mm long, $14.5-15 \mathrm{~mm}$ at the widest part, and $0.7-0.72 \mathrm{~cm}$ at the base, apex emarginate to bilobed with an incision c. $5 \mathrm{~mm}$, various shades of pale yellow with yellow to a deep yellow median band from the tip to the base (divided into two patches like a Y-shape at the base), two rows of short white hairs along both sides of the midrib (the length of each row 8.5-9.5 mm long). Stamen 1; filament flat 4.4-4.5 mm long and $4.5 \mathrm{~mm}$ wide, pubescent. Anther c. $8 \times 2 \mathrm{~mm}$, puberulent, spurred; spurs 3-4mm long; crest very short, slightly longer than the anther lobes, apex retuse. Stigma conical, c. $0.8 \times 0.8 \mathrm{~mm}$, glabrous, ostiole ciliate. Epigynous glands 2, $4.2 \mathrm{~mm}$ long, apex acute, yellow.
Ovary obovoid, $3.6-4.0 \times 2.3-2.5 \mathrm{~mm}$, pale yellow to white, glabrous, ovule with axile placentation. Fruit and seeds not seen.

Common name: "Khamin Siam"-The word "Khamin" comes from the Thai name of Curcuma genus, while "Siam" is the former name of Thailand refer to this species was first discovered and reported from Thailand. And two other names are known and called among the sacred plant collectors in namely "Suwan Phanom" (Suwan" = gold, "Phanom" = Phanom Sarakham District, the first locality which found this species), and the name "Maha Udom Lueang Nuan" ("Maha Udom" = Very plentiful, "Lueang Nuan" = pale yellow refer to the color of flowers of this species).

Phenology: Flowering in late July to September; inflorescence terminal, appearing between the innermost leaves sheaths, emerge almost at the base of pseudostems, flowers fully open in the early morning and last a single day. Leafy shoot emerging in April and dormancy begins in November.

Distribution: Recently found only in the type locality in Chachoengsao Province, Southeastern Thailand (Figure 1).

Ecology: It grows in sandy loam soil, well-drained, in the mixed-deciduous forest, at elevation 140-250 $\mathrm{m}$ above sea level.

Etymology: The specific epithet "siamensis" is named from the former name of Thailand, refers to the geographical origin of this new species.

Uses: Auspicious ornamental plant.

Provisional IUCN conservation assessment. This species is only known in Chachoengsao province which is non-protected area. Our survey found this species in total was less than 500 individuals, but there is the presence of suitable locations which limited access to surveys nearby e.g. Khao Ang Ru Nai Wildlife Sanctuary and other nearby National Park. Therefore, we consider ranking this species as Data Deficient (DD) category, following the IUCN criteria (2019), Although this species has a high risk of removal from its habitats as it was sold in many online groups which mostly are taken directly from the wild. We hope to find this species more and more in the future surveys in nearby unexplored areas to further change its conservation status to a suitable one.

\section{Discussion}

Curcuma siamensis Saensouk \& Boonma is belongs to the subgenus Ecomatae Škorničk. \&Šída f. (Záveská et al. 2012) since the presence of epigynous glands and anther spurs, lacking conspicuous coma bracts, fertile bracts fused only at the base, and flower open-form. Although the species in the subgenus Curcuma also present epigynous glands but usually with well-developed coma bracts and flowers is usually closed-form. While the species in subgenus Hitcheniopsis lack epigynous glands. Thus this new species fall into Curcuma subgenus Ecomatae.

The appearance of the yellow tone flowers of this new species makes it look like many plants belonging to the same subgenus. A striking contrast to the first species in the same subgenus Ecomatae is Curcuma supraneeana (W.J. Kress \& Larsen) Škorničk., which has the same tone 
of flower's color but produces an elongated peduncle that makes the inflorescences outstanding above the pseudostems while $C$. siamensis has a short peduncle and emerged only at the basal of the pseudostems. Considering the appearance of the anther spurs 3-4 mm long makes $C$. siamensis different from $C$. arida Škorničk. \& N.S. Lý, $C$. chantaranothaii Boonma \& Saensouk, C. cochinchinensis Gagnep., C. eburnea Škorničk., Suksathan \& Soonthornk., C. pambrosima Škorničk. \& N.S. Lý, C. pierreana Gagnep., C. pitukii Maknoi, Saensouk, Rakarcha \& Thammar, and $C$. vitellina Škorničk. \& H.Đ. Trần. which all seven species mentioned have anther spurs filamentous and very short or not over $2 \mathrm{~mm}$ long. Especially $C$. pambrosima and $C$. pierreana have staminodes with purple whereas the staminodes of $C$. siamensis without purple.

In addition, when compared to species that have spurs longer than $2 \mathrm{~mm}$ long. They were found to be able to divide them in considering by the position of inflorescences for easy comparison. Firstly, compared to the species which produced lateral inflorescence directly from the rhizome and also have a similar color of flowers but differ in having purple staminodes or with purple at the base of staminodes namely $C$. ecomata Craib, C. corniculata Škorničk., and C. glans Larsen \& Mood. (VS. C. siamensis have pale yellow staminodes without purple). While other species produced lateral inflorescences directly from the rhizome, namely $C$. aruna Maknoi \& Saensouk, $C$. candida (Wall.) Techapr. \&Škorničk., C. flaviflora S.Q. Tong, $C$. newmanii Škorničk., C. sahuynhensis Škorničk. \& N.S. Lý, C. singularis Gagnep., C. tongii Y.H. Tan \& L.X. Zhang., and $C$. xanthella Škorničk. are included in the comparison but differ in many parts as well. However, albeit it can be separated by the position of the inflorescence, some species in the Curcuma genus are not stable about the position of producing inflorescences character which is likely to form inflorescences in both positions; for example, in Curcuma angustifolia Roxb., thus we need to compare all parts of them in morphological characteristics for accuracy and completeness of the study results, which finally $C$. siamensis produced only terminal inflorescence and not matched with any species of Curcuma that produced lateral inflorescence.

Subsequently, compared to the remainder of the species which produced terminal inflorescence in the same subgenus Ecomatae, which consists of Curcuma bicolor Mood \& K. Larsen, C. cinnabarina Škorničk. \& Soonthornk., $C$. cotuana Luu, Škorničk. \& H.Đ.Trần, $C$. flammea Škorničk., C. kayahensis Nob. Tanaka \& M. M. Aung, C. peramoena Souvann. \& Maknoi, C. putii Maknoi \& Jenjitt., C. rangsimae Boonma \& Saensouk, C. rhomba Mood \& Larsen, C. stenochila Gagnep., C. stolonifera N. Tanaka, K. Armstrong \& M. M. Aung, and C. woodii N. H. $\mathrm{Xia} \&$ J. Chen. From the twelve species mentioned, four species, namely C. rhomba, C. woodii, C. peramoena, and $C$. putii have staminodes with dark red or dark purple spots at the base, two species namely $C$. bicolor and C. flammea have staminodes with lower half red to dark red. Based on these traits make all six of these species different from $C$. siamensis which has staminodes in yellow tone without red or purple at the base.

Considering the remaining species about the basal of leaves appearance, there are three species with leaves base rounded to cordate and with reddish corolla lobes namely C. cinnabarina, C. stenochila, and C. kayahensis, whereas $C$. siamensis has leaves base attenuate. And the last comparison to these three species namely $C$. cotuana, $C$. rangsimae, and $C$. stolonifera to $C$. siamensis which all of them have leaves glabrous on both sides except in $C$. rangsimae has a few hairy at the tip of leaves. Curcuma stolonifera has a reddish patch along its midrib as in $C$. siamensis, but it has closed-form flowers, and an inflorescence terminal but does not emerge at basal of pseudostems make it differ from $C$. siamensis. Comparison of the morphological characteristic of $C$. siamensis with $C$. rangsimae from a neighbor area and $C$. cotuana from Vietnam in Table 1, anther comparison of $C$. siamensis and its allies species in side view and front view under the same scale in Figure 2, and a revised key to 21 species of Curcuma subgenus Ecomatae in Thailand for facilitating identification is also prepared.

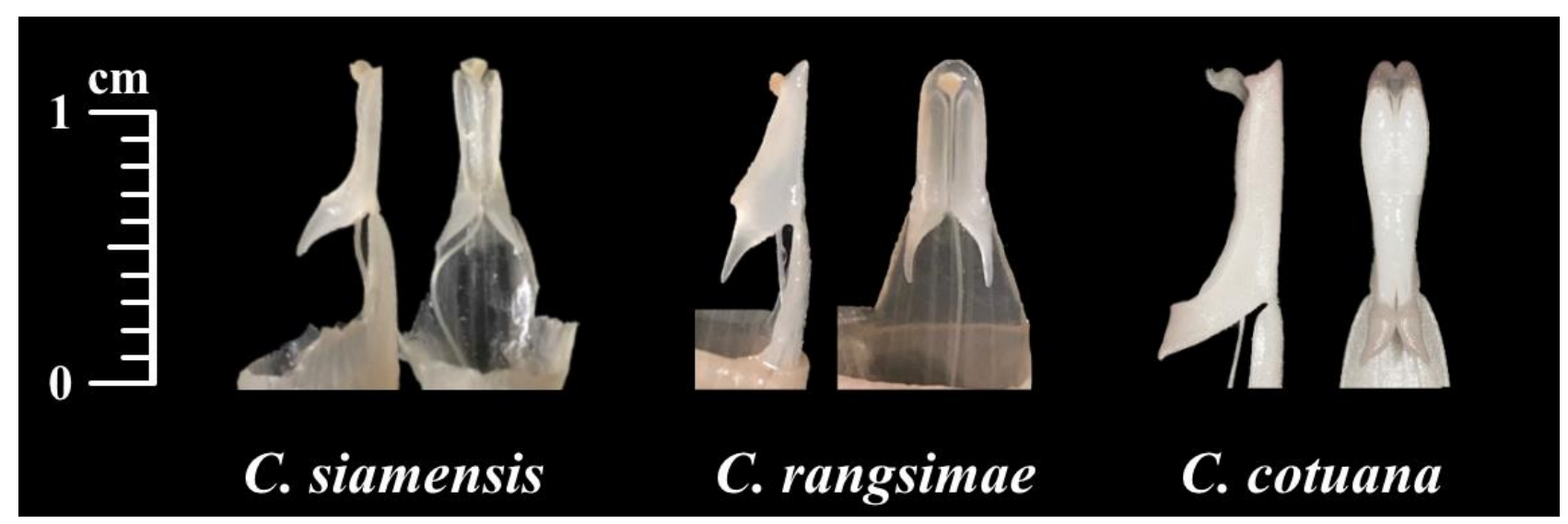

Figure 2. Anther comparison of Curcuma siamensis Saensouk \& Boonma sp. nov. and its allies species in side view and front view under the same scale. Photographs by Thawatphong Boonma 

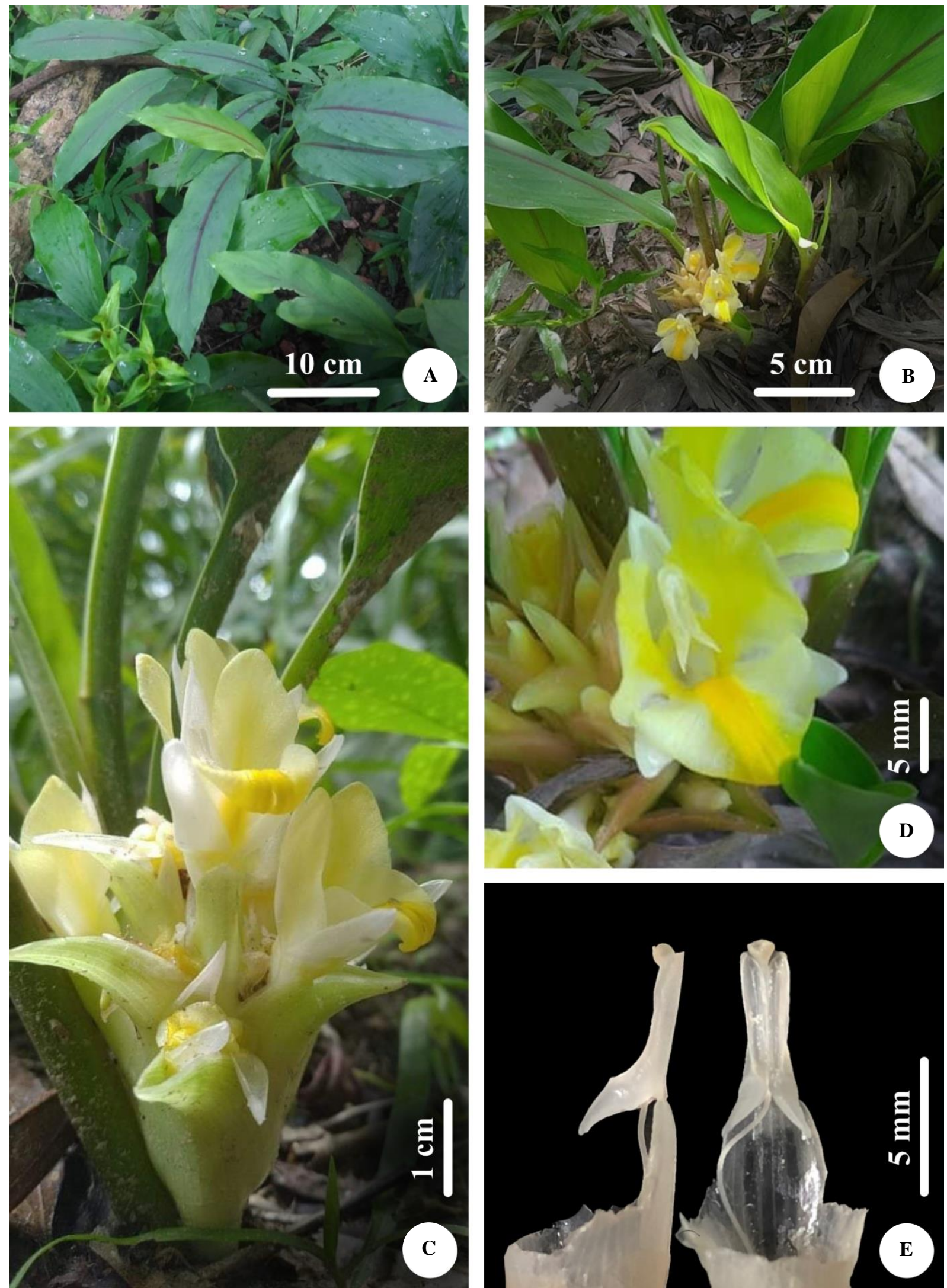

Figure 3. Curcuma siamensis Saensouk \& Boonma sp. nov. (A) Natural habitat in oblique-top view, C. siamensis (red midrib) grows near $C$. harmandii Gagnep., (B) plants with inflorescence and flowers in oblique-top view, (C) inflorescence with flowers in side view, (D) flower-front view, (E) anther-side and front view. Photographs A-D by N. Wannaphirun; E by Thawatphong Boonma 

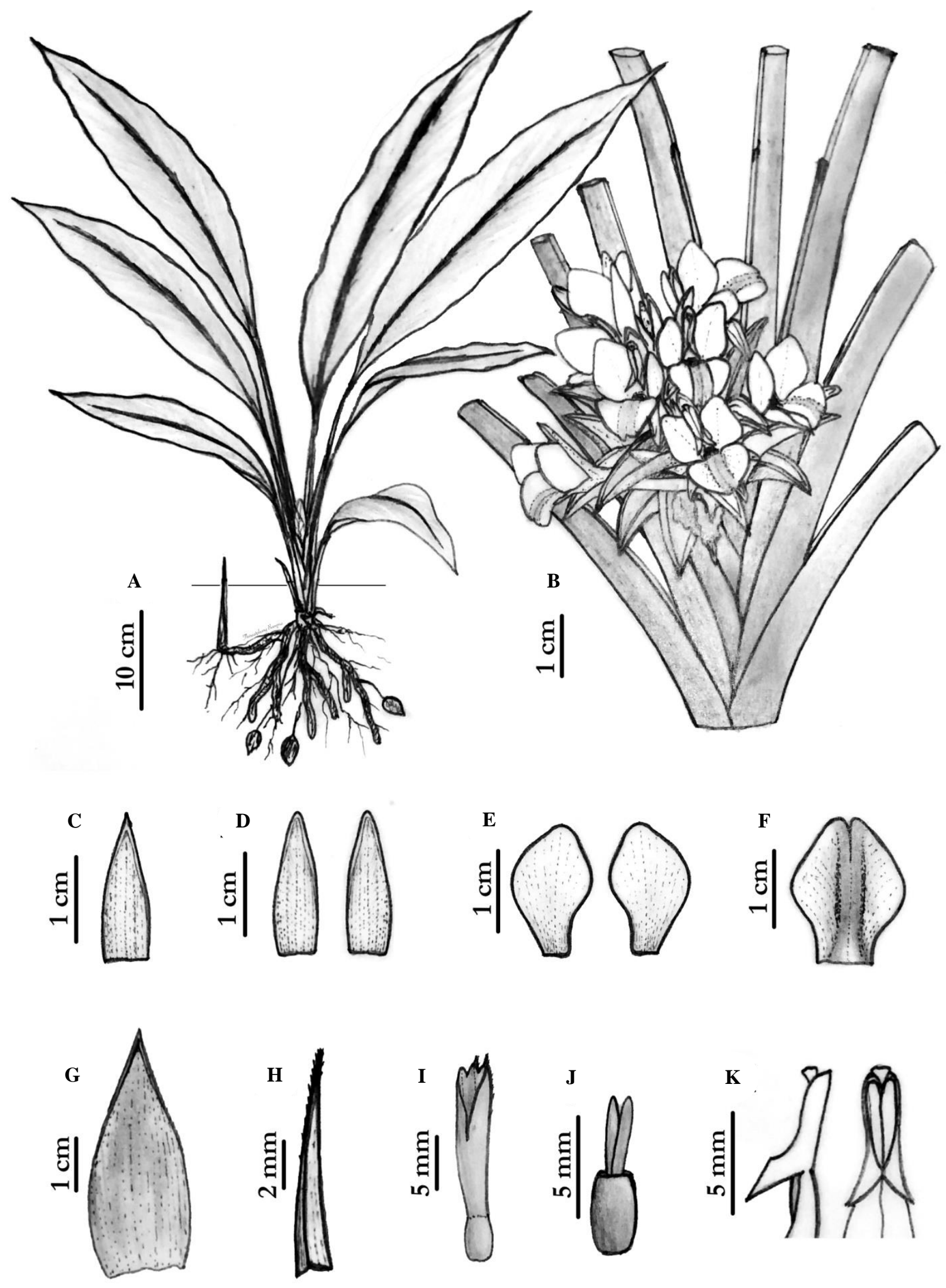

Figure 4. Curcuma siamensis Saensouk \& Boonma sp. nov. (A) habit, (B) side view of terminal inflorescence in the leaf-sheaths, (C) dorsal corolla lobe, (D) lateral corolla lobes, (E) staminodes, (F) labellum, (G) bract, (H) bracteole, (I) calyx with ovary, (J) epigynous glands with ovary, (K) side and front view of anther. Drawn by Thawatphong Boonma 
Table 1. Morphological comparison of Curcuma siamensis and its allies species

\begin{tabular}{|c|c|c|c|}
\hline Characters & $\begin{array}{l}\text { Curcuma siamensis } \\
\text { Saensouk \& Boonma }\end{array}$ & $\begin{array}{l}\text { Curcuma rangsimae } \\
\text { Boonma \& Saensouk } \\
\text { (Saensouk et al. 2021) }\end{array}$ & $\begin{array}{l}\text { Curcuma cotuana Luu, Škorničk. } \\
\text { \& H.Đ.Trần } \\
\text { (Luu et al. 2017) }\end{array}$ \\
\hline Rhizome-size (cm) & $2-3 \times 1.8-2.5$ & $3.6-4 \times 2.5-3.1$ & $1.0-2.7 \times 0.4-1.0$ \\
\hline Leaf-sheaths & Glabrous & Glabrous & $\begin{array}{l}\text { Glabrous at base, sparsely pilose } \\
\text { towards the margins and upper part }\end{array}$ \\
\hline Leaves-shape & Narrowly elliptic & $\begin{array}{l}\text { Narrowly elliptic to } \\
\text { oblanceolate }\end{array}$ & Elliptic to ovate \\
\hline Leaves-size $(\mathrm{cm})$ & $18-36 \times 6-8.5$ & $40-70 \times 12-20$ & $38.5 \times 13.0$ \\
\hline Leaves-base & Attenuate & Attenuate-slightly oblique & Rounded to cordate \\
\hline Leaves-upper midrib & Reddish & Green & Green \\
\hline Leaves-surfaces & Glabrous on both surfaces & $\begin{array}{l}\text { Glabrous on both surfaces } \\
\text { except a few shortly hairy at tip }\end{array}$ & Glabrous on both surfaces \\
\hline Thyrse & $\begin{array}{l}5-6.5 \mathrm{~cm} \text { long, } \\
4-5 \mathrm{~cm} \text { in diam. }\end{array}$ & $\begin{array}{l}12-20 \mathrm{~cm} \text { long, } \\
7.8-9.5 \mathrm{~cm} \text { in diam. }\end{array}$ & $\begin{array}{l}5-9 \mathrm{~cm} \text { long, } \\
5.5-6.5 \mathrm{~cm} \text { in diam. }\end{array}$ \\
\hline Peduncle & Glabrous & Pilose & Sparsely pilose \\
\hline $\begin{array}{l}\text { Bracts-number per } \\
\text { inflorescence }\end{array}$ & $10-15$ & $25-48$ & $16-24$ \\
\hline Bracts-size & $3.5-5.4 \times 1-2.8 \mathrm{~cm}$ & $3.4-3.9 \times 2.6-3.2 \mathrm{~cm}$ & $2.5-3.8 \times 1.7-2.2 \mathrm{~cm}$ \\
\hline Bracts-apex & Mucronate & Obtuse to acute & Acute \\
\hline Bracts-surfaces & Puberulent & Pilose & Glabrous \\
\hline Bracts-connate in basal & Fused almost only at base & $1 / 4-1 / 3$ at base & $1 / 2-2 / 3$ at base \\
\hline Bracteoles & $\begin{array}{l}\text { Ciliate, } \\
8-14 \mathrm{~mm} \text { long, }\end{array}$ & $\begin{array}{l}\text { Glabrous, } \\
6-10 \mathrm{~mm} \text { long }\end{array}$ & $\begin{array}{l}\text { Glabrous, sometimes reduced, } \\
2-6 \mathrm{~mm} \text { long }\end{array}$ \\
\hline Calyx & $\begin{array}{l}\text { White, } \\
18.3-18.5 \mathrm{~mm} \text { long, } \\
\text { A few hairy at the margin of } \\
\text { the three lobes }\end{array}$ & $\begin{array}{l}\text { Translucent white, } \\
\text { 12-20 mm long, } \\
\text { Glabrous }\end{array}$ & $\begin{array}{l}\text { Semi-translucent red, } \\
20-22 \text { mm long, } \\
\text { Glabrous, sometimes sparsely } \\
\text { puberulent }\end{array}$ \\
\hline Floral tube & Pale yellow to white at base & Pale yellow to white at base & $\begin{array}{l}\text { Red tinge towards apex, cream white } \\
\text { at base }\end{array}$ \\
\hline Dorsal corolla lobe & $\begin{array}{l}\text { White, } \\
17.6-18.3 \times 7.6-7.8 \mathrm{~mm}, \\
\text { apex mucronate (mucro c. } 3 \\
\text { mm long) }\end{array}$ & $\begin{array}{l}\text { Light pale yellow, } \\
16-17 \times 10-12 \mathrm{~mm} \text {, } \\
\text { apex acuminate }\end{array}$ & $\begin{array}{l}\text { Red, } \\
22-24 \times 6-7 \mathrm{~mm} \text {, } \\
\text { apex mucronate (mucro c. } 1 \mathrm{~mm} \\
\text { long) }\end{array}$ \\
\hline Lateral corolla lobes & $\begin{array}{l}\text { White, } \\
17.0-17.5 \times 6.3-6.5 \mathrm{~mm}\end{array}$ & $\begin{array}{l}\text { Light pale yellow, } \\
15-17 \times 9-11 \mathrm{~mm}\end{array}$ & $\begin{array}{l}\text { Pale orange-red, } \\
20-22 \times 5-6 \mathrm{~mm}\end{array}$ \\
\hline Staminodes & $\begin{array}{l}\text { Uniquely obovate-rhombic, } \\
\text { 16.2-16.8 mm long, } \\
\text { Pale yellow }\end{array}$ & $\begin{array}{l}\text { Asymmetrical trullate-ovate, } \\
14-16 \mathrm{~mm} \text { long, } \\
\text { Pale yellow }\end{array}$ & $\begin{array}{l}\text { Unequally ovate to rhomboid, } \\
19-21 \mathrm{~mm} \text { long, } \\
\text { Orange }\end{array}$ \\
\hline Labellum & $\begin{array}{l}\text { ovate-trullate, } \\
17.8-18.2 \mathrm{~mm} \text { long, } \\
\text { Yellow }\end{array}$ & $\begin{array}{l}\text { Ovate, } \\
15-16 \mathrm{~mm} \text { long, } \\
\text { Yellow }\end{array}$ & $\begin{array}{l}\text { Rhomboid, } \\
21-23 \mathrm{~mm} \text { long, } \\
\text { Orange }\end{array}$ \\
\hline Filament & 4.4-4.5 mm long & 6-7 mm long & $7 \mathrm{~mm}$ long \\
\hline Anther & c. $8 \mathrm{~mm}$ long & $6.3-6.9 \mathrm{~mm}$ long & $12.5 \mathrm{~mm}$ long \\
\hline Anther spurs & $\begin{array}{l}3-4 \mathrm{~mm} \text { long } \\
\text { Pointing outward }\end{array}$ & $\begin{array}{l}2.8-3.4 \mathrm{~mm} \text { long } \\
\text { Pointing downward }\end{array}$ & $\begin{array}{l}3.5-4.0 \mathrm{~mm} \text { long, } \\
\text { Pointing outward }\end{array}$ \\
\hline Anther thecae & $4 \mathrm{~mm}$ long & $4 \mathrm{~mm}$ long & $8 \mathrm{~mm}$ long \\
\hline Anther crest-apex & Retuse & Rounded & Bi-lobed \\
\hline Ovary & $\begin{array}{l}3.6-4.0 \mathrm{~mm} \text { long } \\
\text { Pale yellow, } \\
\text { Glabrous }\end{array}$ & $\begin{array}{l}3.5-4.0 \mathrm{~mm} \text { long, } \\
\text { Light pale yellow, } \\
\text { Glabrous }\end{array}$ & $\begin{array}{l}\text { c. } 3 \mathrm{~mm} \text { long, } \\
\text { Cream with a red tinge, } \\
\text { Densely pilose }\end{array}$ \\
\hline
\end{tabular}

\section{Key to 21 species of Curcuma subgen. Ecomatae in Thailand}

1. Floral tube longer than bracts, narrow; flowers yellow; petiole very distinct from leaf blade

1. Floral tube short, wide, flowers of various colors, leaf-blade tapering into the petiole

2. Anther spurs filamentous, $<2 \mathrm{~mm}$ long

3. Staminodes with dark purple tips

C. pierreana

3. Staminodes without dark purple tips

4. Leave puberulous on both surfaces

4. Leave adaxially surface glabrous

5. Rhizome crawling; leaves base attenuate

5. Rhizome ovoid; leaves base cuneate to rounded, or sub-cordate

6. Calyx white, glabrous; filament short c. $2 \mathrm{~mm}$ long; anther $8-9 \mathrm{~mm}$ long

6. Calyx pale purple, puberulent; filament $5-8 \mathrm{~mm}$ long; anther $2.5-4 \mathrm{~mm}$ long

C. chantaranothaii

C. cochinchinensis

C. eburnea

C. pitukii 
2. Anther spurs conical or cylindrical, $>2 \mathrm{~mm}$ long

7. Inflorescence terminal

8. Leaves adaxially surface glabrous

9. Staminodes without red spots at the base

10. Midrib adaxially green

C. rangsimae

10. Midrib adaxially green with red patch

C. siamensis

9. Staminodes with dark red or dark purple spots at the base

11. Leaves abaxially glabrous; labellum yellow with inside half orange C. rhomba

11. Leaves abaxially pubescent; labellum not as above

12. Labellum sub-orbicular, white with an orange median band and deep purple lines at the base; staminodes white with orange tip

12. Labellum diamond-shaped, white with a yellow median band and red spots at the base; staminodes white without orange tip

8. Leaves adaxially surface with hairy along the veins or pubescent

13. Corolla lobes whitish-green to pale green; leaves base cuneate to attenuate

13. Corolla lobes pink, red or purple; leaves base oblique, rounded or cordate

14. Staminodes lower half dark red, upper half orange-yellow

14. Staminodes pale yellow to yellow

15. Thyrse $<10 \mathrm{~cm}$ long; flowers open form; corolla lobes red

15 . Thyrse $>10 \mathrm{~cm}$ long; flowers closed form; corolla lobes white to pale yellow

7. Inflorescence lateral

16. Staminodes purple

16. Staminodes white or yellow

17. Labellum yellow

18. Staminodes ovate to elliptic; leaves base cuneate

18. Staminodes obovate; leaves base rounded

C. woodii

. peramoena

C. putii

C. bicolor

C. stenochila

C. cinnabarina

C. ecomata

17. Labellum white with yellow median band

19. Leaves adaxially with red patch along the midrib

C. aruna

19. Leaves adaxially with green midrib

20. Staminodes lower half white, upper half yellow, central with purple patch

20. Staminodes white

C. candida

C. glans

C. singularis

\section{ACKNOWLEDGEMENTS}

This research project is financially supported by Mahasarakham University, Thailand. We would like to thank Walai Rukhavej Botanical Research Institute (WRBRI), Mahasarakham University, for supporting us. Warm thanks to Professor Dr. Pranom Chantaranothai, the director and all curators of Khon Kaen University's Herbarium (KKU) for processing our herbarium specimens, Brio Botanical Research Garden (BBRG), our family, and our botanist friends who supported us as well as to all curators of all local herbaria visited. Also, special and warm thanks to Nutthawut Wannaphirun for allowing us to use his beautiful photographs, thanks to all reviewers for valuable suggesting us and thanks to all supporters who are not mentioned here for their facilities during this study.

\section{REFERENCES}

Kew Science. 2021. World checklist of selected plant families (WCSP). http://apps.kew.org/wcsp/
Larsen K, Larsen SS. 2006. Gingers of Thailand. Queen Sirikit Botanic Garden, The Botanical Garden Organization,Chiang Mai, Thailand.

Leong-Škorničková J, Newman M. 2015. Gingers of Cambodia, Laos \& Vietnam. Singapore Botanic Garden, National Parks Board, Singapore.

Leong-Škorničková J, Šida O, Záveská E, Marhold K. 2015. History of infrageneric classification, typification of supraspecific names and outstanding transfers in Curcuma (Zingiberaceae). Taxon 64 (2): 362373. DOI: $10.12705 / 642.11$.

Maknoi C, Saensouk S, Saensouk P, Rakarcha S, Thammarong W. 2021. Two new species of Curcuma L. (Zingiberaceae) from Thailand. Biodiversitas 22 (9): 3910-3921. DOI: 10.13057/biodiv/d220937.

Saensouk S, Boonma T, Saensouk P. 2021. Six new species and a new record of Curcuma L. (Zingiberaceae) from Thailand. Biodiversitas 22 (4): 1658-1685. DOI: 10.13057/biodiv/d220410.

Sirirugsa P, Larsen K, Maknoi C. 2007. The genus Curcuma L. (Zingiberaceae): Distribution and classification with reference to species diversity in Thailand. Gard Bull Sing 59 (1\&2): 203-220.

Sirirugsa P. 1966. The genus Curcuma L. (Zingiberaceae) in Thailand. Prince of Songkla University, Hat Yai, Thailand.

Záveská E, Fér T, Šida O, Krak K, Marhold K, Leong-Škorničková J. 2012. Phylogeny of Curcuma (Zingiberaceae) based on plastid and nuclear sequences: Proposal of the new subgenus Ecomata. Taxon 61 (4): 747-763. DOI: 10.1002/tax.614004. 